\title{
Response of Potato Varieties to Potassium Levels in Hamelmalo Area, Eritrea
}

\author{
Daniel Zeru Zelelew ${ }^{1} \&$ Biniam Mesfin Ghebreslassie ${ }^{1,2}$ \\ ${ }^{1}$ Department of Horticulture, Hamelmalo Agricultural College, Eritrea \\ ${ }^{2}$ Deprtment of Horticulture, Jomo Kenyatta University of Agriculture and Technology, Kenya \\ Correspondence: Biniam Mesfin Ghebreslassie, Department of Horticulture, Hamelmalo Agricultural College, \\ Eritrea; Deprtment of Horticulture, Jomo Kenyatta University of Agriculture and Technology, Kenya. E-mail: \\ bm95913@yahoo.com
}

Received: October 12, 2015 Accepted: November 6, 2015 Online Published: November 21, 2015

doi:10.5539/jps.v5n1p11 URL: http://dx.doi.org/10.5539/jps.v5n1p11

\begin{abstract}
Poor soil fertility and lack of high yielding certified varieties are of the major potato production tribulations in Eritrea. Top soils are continually removed due to water run-off and thus soil fertility and productivity has declined as a result. An experiment was designed to assess the response of potato varieties to different levels of potassium application at Hamelmalo Agricultural College, Eritrea. Three varieties (Ajiba, Zafira and Picasso) and five potassium levels $\left(0,75,150,225\right.$ and $\left.300 \mathrm{~kg} \mathrm{~K}_{2} \mathrm{O} / \mathrm{ha}\right)$ along with all possible interactions were used. Experimental design following factorial Randomized Complete Block Design (RCBD) in three replications was employed. Data was collected on yield and tuber quality parameters. The result of the study indicated that there were significant variations in the performances of varieties in terms of yield and quality parameters in which Ajiba was found to be more responsive and high yielding. Tuber number, tuber diameter, tuber weight per plant, total yield, total soluble solids, specific gravity and tuber moisture content showed significant differences due to the application of potassium. As a result, the highest tuber weight (1.14 kg/plant) and yield (49.38 tones/ha) were recorded from Ajiba treated with $300 \mathrm{~kg} \mathrm{~K} \mathrm{~K}_{2} \mathrm{O} / \mathrm{ha}$. The result further revealed that there is a promising profit return by investing more on potassium application upto $300 \mathrm{~kg} \mathrm{~K}_{2} \mathrm{O} / \mathrm{ha}$. It is, thus, recommended that potassium fertilizers should be introduced to optimize productivity in Hamelmalo area, Eritrea.
\end{abstract}

Keywords: Eritrea, potassium fertilizer, potato, varieties, tuber yield and quality

\section{Introduction}

Potato (Solanum tuberosum L.) is the fourth major food crop, next to wheat, rice and maize (Rana, 2008). It is highly recommended food security crop that can safe guard low-income countries from the risks posed by rising international food prices (FAO, 2009). It is a source of both food and income in many of the densely populated highlands of Sub-Saharan Africa. Taking into consideration the prospect for growth in the market for fresh potatoes and the current international market conditions characterized by high prices of cereals, potato can be taken as a good benchmark for rural development in sub-Saharan Africa (Gildemacher et al., 2009). In the last few years potato is becoming one of the priority crops in the highland and midland of Eritrea more particularly in Zoba Maekel and Zoba Debub (Biniam, Githiri, Tadesse, \& Kasili, 2014). It is widely grown by small-scale farmers, contributing to food security as a direct food source and cash crop (MoA, 2010), with low input and low output practice, in an estimated total area of 2, 000 ha (Biniam et al., 2014). Land holding and yield of potato varies among farmers and sites but it was estimated to be 12 tones/ha on average (MoA, 2010) which is very low as compared with international and regional standards.

Potato is a short duration, high yielding and exhaustive crop. Balanced use of nutrients is essential for sustainable productivity of crops. In many potato producing areas nitrogen $(\mathrm{N})$ and phosphorus $(\mathrm{P})$ fertilizers are being used while potassium $(\mathrm{K})$ application is ignored which causes serious decrease in the status of potassium in soils of potato growing areas (Pervez, Ayyub, Shabeen, \& Noor, 2013). This is particularly true to Eritrean case due to the assumption that the soil is developed from $\mathrm{K}$ rich parent material and contains sufficient amount of $\mathrm{K}$ to support crop growth. However, this assumption is based on the work done before forty-seven years by Murphy (1968), which indicated that the available K content of most Ethiopian (including Eritrean) soils is high. The most commonly used fertilizer types currently in Eritrea are Di-ammonium Phosphate (DAP), urea and 
farmyard manure (Biniam et al., 2014). Potassium has a crucial role in higher productivity of potato tubers because it plays an important role in photosynthesis, regulation of opening and closing of stomata, favours high energy status which helps in timely and appropriate nutrient translocation and water uptake in plants (Bergmann, 1992). Besides, adequate supply of $\mathrm{K}$ can help to reduce internal blackening and mechanical damage, and has been associated with increased stress tolerance (FAO, 2009). Potassium is an essential nutrient for all plants and has a major effect upon yield and quality of potatoes as well as the general health and vigor of the crop (Abd El-Latif, Osman, Abdullah, \& Abdelkader, 2011). Abay and Sheleme (2011) found that the highest tuber yield (53.33 t/ha) which is $11.4 \%$ yield advantage over the control from application of $280 \mathrm{~kg} \mathrm{~K} / \mathrm{ha}$.

Potato seeds used in Eritrea consist of a mixture of many cultivars that were originally imported and seed tubers that have been saved from these over many generations by local farmers (MoA, 2010). Reports of the Ministry of Agriculture, the State of Eritrea (2012) had indicated that the high cost and shortage of inputs especially seeds; fungicides and fertilizers have severely limited their application. Potatoes grow in Eritrea both under rain fed and irrigated condition often in small parcels of lands with limited resources. To improve soil fertility, farmers apply manures and fertilizers only when they are available and affordable (Biniam et al., 2014). The dose, time and methods of application are so different among the farmers from different area of production, the authors added. Several recent research activities to improve and optimize productivity and quality of potato through the application of $\mathrm{K}$ have been reported in other countries and promising results have been obtained and recommended by the authors (Abay \& Sheleme, 2011; Abubaker, AbuRayyan, Amre, Alzubil, \& Haidi, 2011; Noor, 2010; Wassie, 2009). However, no similar research was conducted on the response of potato varieties to K levels in Eritrea. An experiment was, therefore, designed to carry a field experiment at Hamelmalo area. Promising results were obtained and their application will immensely boost up potato productivity in Eritrea.

\section{Materials and Methods}

The research project was carried out in the Research Farm, of Hamelmalo Agricultural College; Hamelmalo,

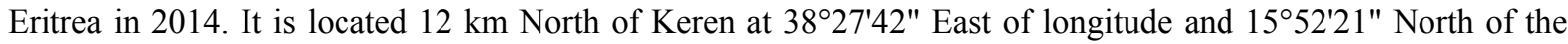
latitude. It is situated at an altitude of 1285 meters above the sea level. The climate of the area is semi-arid with $429.1 \mathrm{~mm}$ annual rain fall for the growing season. Prior to planting of the potato crop, nine soil samples from different areas of the experimental blocks were taken with the help of an auger at 0-30 $\mathrm{cm}$ depth. Composite and representative soil sample was prepared thorough mixing of samples taken. It was air dried and then passed through $2 \mathrm{~mm}$ sieve, the soil sample was analyzed and its physico-chemical properties are shown in Table 1.

The field was thoroughly ploughed two times and harrowed once to a fine texture before clearing and leveling. Farmyard manure (FYM) of $20 \mathrm{t} / \mathrm{ha}$ was applied as recommended by (Rana, 2008). Urea (N) and DAP $\left(\mathrm{P}_{2} \mathrm{O}_{5}\right)$ were applied at 225 and $135 \mathrm{~kg} / \mathrm{ha}$, respectively as per the recommendation of Hochmuth and Hanlon (2000). All doses of FYM and $\mathrm{P}$ and half dose of $\mathrm{N}$ were applied uniformly to all the treatments during field preparation. The remaining half dose of $\mathrm{N}$ was applied 30 days after planting. The experiment was laid out in factorial arrangement Randomized Complete Block Design (RCBD) with three replications. The treatments consisted of three varieties of potato (Ajiba, Zafira and Picasso) and five K levels (0, 75, 150, 225 and 300).

Table 1. Physico-Chemical properties of the experimental field soil at $30 \mathrm{~cm}$ depth

\begin{tabular}{llll}
\hline Chemical analysis & \multicolumn{3}{l}{ Chemical analysis } \\
\hline Sand \% & 61.9 & $\mathrm{~N} \%$ & 0.03 \\
Clay \% & 13.2 & $\mathrm{P}(\mathrm{ppm})$ & 1.07 \\
Silt \% & 24.9 & $\mathrm{Ca}^{++}(\mathrm{meq} / 100 \mathrm{~g})$ & 16 \\
Soil texture Class & Sandy loam & $\mathrm{Mg}^{++}(\mathrm{meq} / 100 \mathrm{~g})$ & 5 \\
$\mathrm{pH}$ & 8.01 & $\mathrm{~K}^{+}(\mathrm{meq} / 100 \mathrm{~g})$ & 0.09 \\
$\mathrm{EC}(\mathrm{ms} / \mathrm{cm})$ & 0.13 & $\mathrm{Na}^{+}(\mathrm{meq} / 100 \mathrm{~g})$ & 0.29 \\
$\mathrm{OM} \%$ & 0.11 & $\mathrm{CEC}(\mathrm{meq} / 100 \mathrm{~g}$ soil $)$ & 22.8 \\
\hline
\end{tabular}

Full doses of potassium $\left(\mathrm{K}_{2} \mathrm{O}\right)$ were applied through band method at the time of planting as per the treatments to each experimental plot $(3 \times 3 \mathrm{~m})$. Healthy pre-sprouted potato seed tubers were planted at a spacing of $75 \times 30 \mathrm{~cm}$ on $15^{\text {th }}$ September, 2014. Irrigation was applied immediately after planting and subsequent irrigations were given 
as per the requirement of the crop. To avoid any over lapping of inputs, plots were $80 \mathrm{~cm}$ apart from each other. All other cultural practices were done uniformly. Ajiba and Zafira were harvested on $25^{\text {th }}$ December 2014 whereas Picasso was harvested on $15^{\text {th }}$ of January 2015. Data was collected on number of tubers per plant, tuber diameter, tubers weight per plant and tuber yield per hectare at the time of harvest. Specific gravity was determined from the raw tubers by adopting weight-in-air/weight-in-water method as prescribed by CIP (2006). Total Soluble Solids (TSS) was determined using Refract meter. Tuber moisture content was determined using an oven and balance method as described by Kabir and Lemaga (2003) and CIP (2006). The data obtained were subjected to statistical analysis using the analysis of variance by GENSTAT software ( $4^{\text {th }}$ ed) and IBM SPSS statistical package version 20 at $5 \%$ level of significance (95\% confidence limit) for the analysis of variance.

\section{Results and Discussions}

\subsection{Yield and Yield Components}

All yield and yield components studied in the present investigation were significantly influenced by the applied levels of $\mathrm{K}$ and varieties. However, only tuber number per plant was found to be significantly affected by the interaction treatments of $\mathrm{K}$ and varieties.

\subsubsection{Tuber Number per Plant}

Number of tubers per plant had shown gradual and significant $(\mathrm{p}<0.001)$ increase within creasing K levels (Table 2). The highest tuber number per plant (9.08) was obtained from the application of $300 \mathrm{~kg} \mathrm{~K}_{2} \mathrm{O} / \mathrm{ha}$ while the lowest (6.92) was obtained from control. In a similar study Adhikary and Karki (2006) and Wibowo, Wijaya, Sumartono, and Pawelzik (2014) found that addition of $\mathrm{K}_{2} \mathrm{SO}_{4}$ fertilizer increased numbers of tubers produced. This could be due to the significant role of $\mathrm{K}$ on photosynthesis, favors high energy status which helps the crop for timely and appropriate nutrients translocation and water absorption by roots resulting in more availability of photo synthates to produce more number of tubers per plant (Bergmann, 1992). There was significant $(p<0.001)$ difference among potato varieties as well in their production of tubers per plant. The highest number of tubers per plant (11.11) was produced by Ajiba followed by Zafira (8.58). This is ascribed to the existence of differences among genotypes in their adaptability to the specific environment and nutrient use efficiency (Wassie, 2009). The interaction effect of $\mathrm{K}$ level and potato varieties on number of tubers per plant was statistically significant. Ajiba responded more to $\mathrm{K}$ up to $150 \mathrm{~kg} \mathrm{~K}$ O/ha. Zafira showed slow increase in tuber number produced in response to $\mathrm{K}$ in the range of 0 to $225 \mathrm{~kg} \mathrm{~K}_{2} \mathrm{O} /$ ha but showed higher response as $\mathrm{K}$ level increased beyond $225 \mathrm{~kg} \mathrm{~K} \mathrm{~K}_{2} \mathrm{O} / \mathrm{ha}$. Picasso showed steady response and number of tubers produced increased gradually with every increase of $\mathrm{K}$ levels (Table 2). Both Zafira and Picasso produced their higher number of tubers 10.57and 5.61, respectively when treated with $300 \mathrm{~kg} \mathrm{~K}_{2} \mathrm{O}$ /ha (Figure 1). All the varieties produced minimum number of tubers per plant at zero application (control). The results speculates that application of more than 150 $\mathrm{kg} \mathrm{K}_{2} \mathrm{O} / \mathrm{ha}$ for Ajiba could be excessive dose that caused reduction in tuber production while it is too low for Zafira and Picasso, as K requirement of potato variety varies (Rana, 2008). Similar results were reported by Ali, Costa, Abedin, Sayed, and Basak (2009) for sweet potato variety.

\subsubsection{Tuber Diameter}

The results shown in Table 2 revealed that $\mathrm{K}$ level increased tuber diameter significantly $(\mathrm{p}<0.001)$. The highest mean value $(5.34 \mathrm{~cm})$ was obtained from application of $225 \mathrm{~kg} \mathrm{~K}_{2} \mathrm{O} / \mathrm{ha}$ and the smallest tuber diameter $(4.77 \mathrm{~cm})$ was recorded from control. Potassium requirement of potatoes increased within creasing tuber size as the functions of $\mathrm{K}$ is related with translocation of carbohydrates from source (leaves) to sink (tuber) resulting in increased tuber size (Adhikary \& Karki, 2006). The fact that the experimental field was poor in K content (Table 1) has led to better response of the crop to $K$ treatment. This is in accordance with the findings of Bansal and Trehan (2011). The authors concluded that $\mathrm{K}$ application increases the size of tubers, especially, in low to medium soil types. Tindall and Westermann (1994) also noted that insufficient $\mathrm{K}$ can result in reduced yields and produced smaller-sized tubers. The varieties had significant variations $(\mathrm{p}<0.001)$ with regard to their response. Picasso which produced larger sized tubers $(5.31 \mathrm{~cm})$ was found to be superior to the other varieties studied. Table 2 indicates that Ajiba which had highest tuber number produced smallest tuber size $(4.84 \mathrm{~cm})$. Similarly, Abong, Okoth, Imungi and Kabira (2010) found that tuber diameter varied significantly among potato cultivars. This could be due to the peculiar genetic characteristics of the varieties: Ajiba, Zafira and Picasso produce large, large oval to long-oval, and very large to large with red eyes tubers, respectively (NIVAP, 2011). However, the varieties did not show any significant difference in response to $\mathrm{K}$ on tuber diameter (Figure 1). 


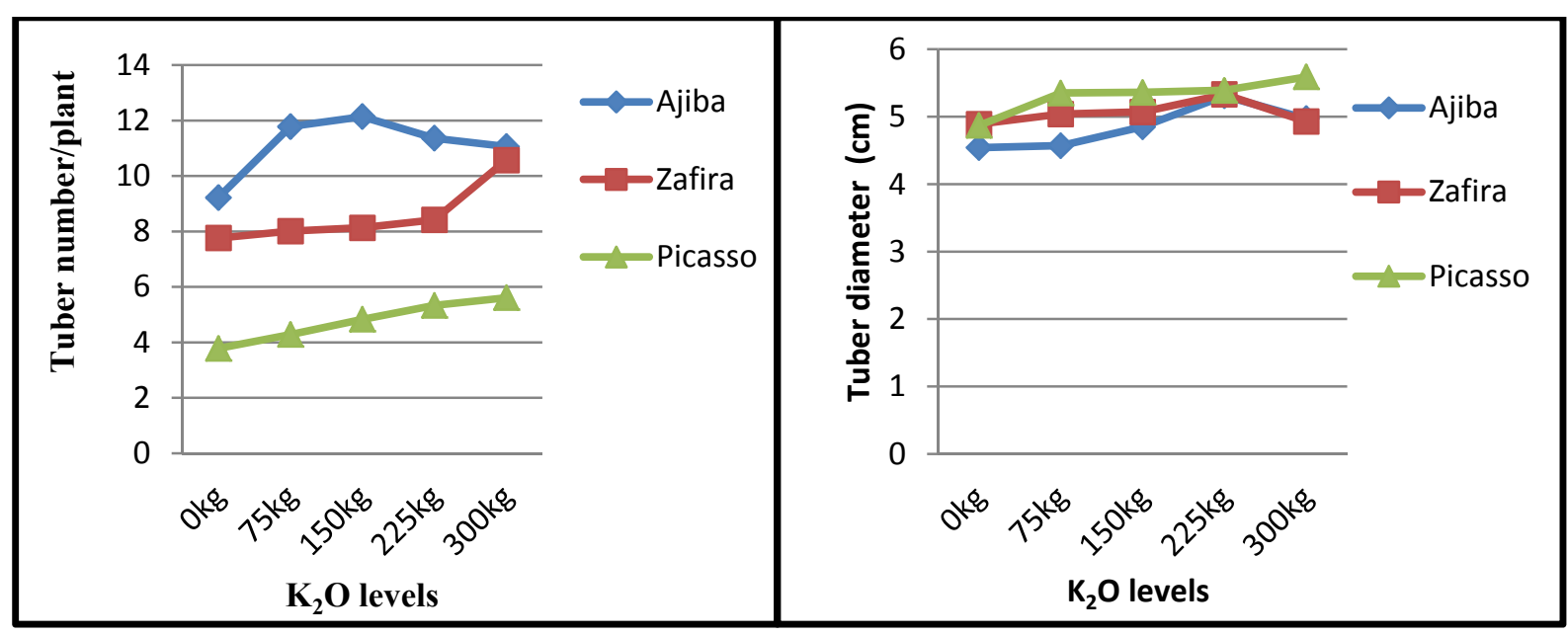

Figure 1. Interaction effects of $\mathrm{K}$ and potato varieties on number of tubers per plant (left) and tuber diameter (right)

\subsubsection{Tuber Weight (kg/plant)}

Increasing $\mathrm{K}$ application from 0 to $300 \mathrm{~kg} / \mathrm{ha}$ had increased tuber weight per plant significantly $(\mathrm{p}<0.001)$. Maximum and minimum mean values of 0.91 and $0.54 \mathrm{~kg}$ per plant were produced from the application of 300 $\mathrm{kg} \mathrm{K}_{2} \mathrm{O} / \mathrm{ha}$ and control, respectively .This is because, higher application of $\mathrm{K}$ facilitates the crop to have better nutrients and water absorption that improve growth and development of the crop and ultimately tuber weight (Bergmann, 1992). Adhikary and Karki (2006) found sharp response of potato to $\mathrm{K}_{2} \mathrm{O}$ application on tuber weight. Table 2 further illustrates that tuber weight per plant had significantly $(p<0.001)$ influenced by varietal treatment. Ajiba was superior of the three varieties evaluated followed by Zafira. In agreement with this finding, Abubaker et al. (2011) reported significant differences between varieties in their seasonal yield and tuber production per plant. Such variation is ascribed to the fact that nutrient usage of potato varies among cultivars and different environmental conditions (Peirce, 1987). Nevertheless, all the varieties exhibited steady increase in their tuber weight with the increase of $\mathrm{K}$ levels (Figure 2). Slight tuber weight decrease was noted at $150 \mathrm{~kg}$ $\mathrm{K}_{2} \mathrm{O} / \mathrm{ha}$ for Ajiba as a result of sudden site specific late blight occurrence few days before the crop maturity.

\subsubsection{Total Yield (t/ha)}

Results in Table 2 revealed that potato tuber yield increased with increasing $\mathrm{K}$ levels and had significant $(\mathrm{p}<0.001)$ differences to all varieties. Highest tuber yield $(40.25 \mathrm{t} / \mathrm{ha})$ which is $39.20 \%$ yield advantage over the control was obtained from the application of $300 \mathrm{~kg} \mathrm{~K}_{2} \mathrm{O} / \mathrm{ha}$. Consistent to the current results, Abd El-Latif et al. (2011) reported that gradual and significant increase of total tuber yield as a result of increased $\mathrm{K}$ level. Highest yield was obtained from the application of $285 \mathrm{~kg} \mathrm{~K}_{2} \mathrm{O} / \mathrm{ha}$, the authors added. This is attributed to the importance of $\mathrm{K}$ in carbohydrate formation and transformation (Van der Zaag, 1981). Moreover, according to Wassie (2009), appreciable increase in yield was noted in response to the application of $\mathrm{K}$ fertilizers, especially from soils with very low or below critical $\mathrm{K}$ level. The varieties investigated also showed significant $(\mathrm{p}<0.001)$ differences (Table 2). Ajiba produced highest tuber yield with 8.67 and $52.09 \%$ yield advantage over Zafira and Picasso, respectively. Contradictory to the current finding Vaezzadeh and Naderidarbaghshahi (2012) noted that the effect of cultivar on tuber yield per unit area was not significant. The interaction between potassium and variety was not found to have any significant influence on the total yield of potato, although there was a trend of increase among the treatments. On contrary Wassie (2009) reported that potato varieties showed significant difference in response to $\mathrm{K}$ application. Maximum yield (49.38 t/ha) was produced from Ajiba treated with $300 \mathrm{~kg} / \mathrm{ha}$ followed by Zafira (45.20 t/ha) (Figure 2). 


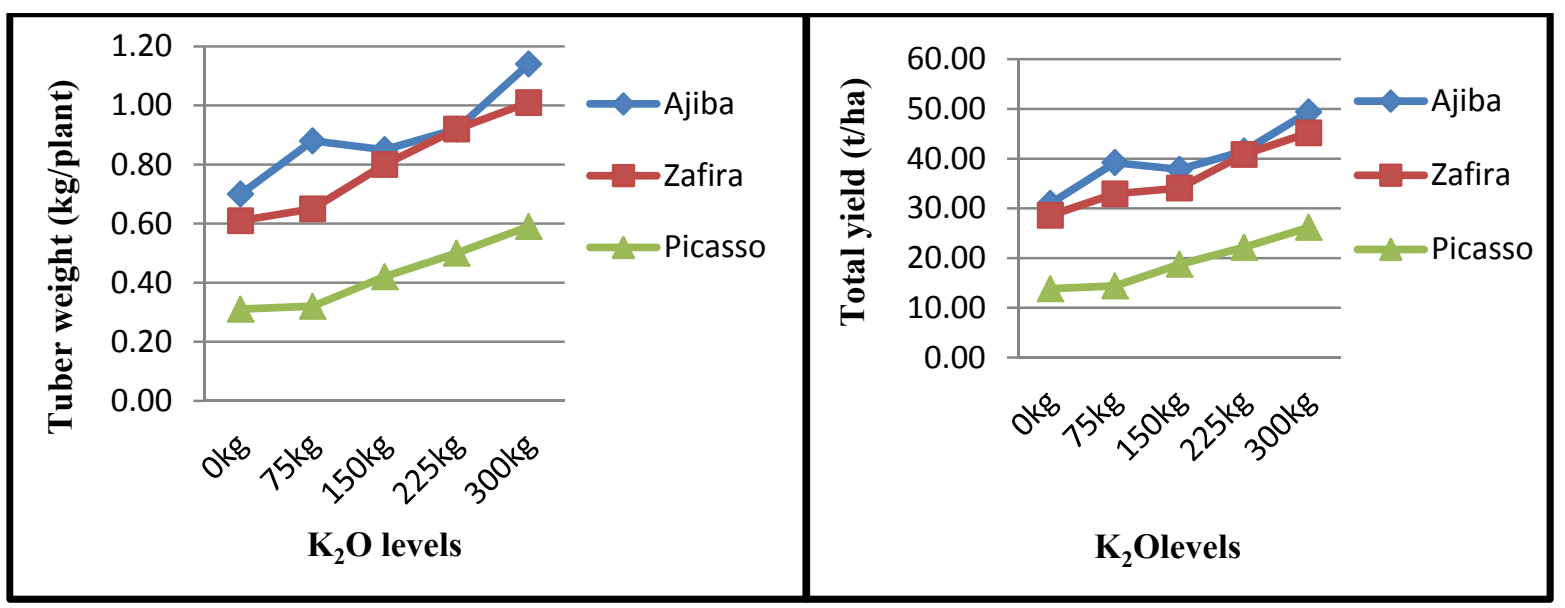

Figure 2. Interaction effects of $\mathrm{K}$ and varieties on tubers weight (left) and tuber yield (right)

Table 2. The effect of potassium and variety on yield and yield components of potato

\begin{tabular}{lcccc}
\hline \multicolumn{1}{c}{$\mathbf{K}_{\mathbf{2}} \mathbf{O}(\mathbf{k g} / \mathbf{h a})$} & $\begin{array}{c}\text { Tuber } \\
\text { number/plant }\end{array}$ & Tuber diameter $(\mathbf{c m})$ & $\begin{array}{c}\text { Tuber weight } \\
\text { (kg/plant) }\end{array}$ & Yield (t/ha) \\
\hline 0 & 6.92 & 4.77 & 0.54 & 24.47 \\
75 & 8.02 & 4.99 & 0.62 & 28.85 \\
150 & 8.37 & 5.09 & 0.69 & 30.22 \\
225 & 8.37 & 5.34 & 0.78 & 34.85 \\
300 & 9.08 & 5.16 & 0.91 & 40.25 \\
LSD & $\mathbf{0 . 8 7 6}$ & $\mathbf{0 . 2 1 4}$ & $\mathbf{0 . 1 2 7}$ & $\mathbf{3 . 4 6 3}$ \\
CV \% & $\mathbf{1 1 . 1 0}$ & $\mathbf{4 . 4 0}$ & $\mathbf{1 8 . 6 0}$ & $\mathbf{1 1 . 3 0}$ \\
Varieties & & & & \\
Ajiba & 11.11 & 4.85 & 9.00 & 39.79 \\
Zafira & 8.58 & 5.05 & 0.80 & 36.34 \\
Picasso & 4.77 & 5.31 & 0.43 & 19.06 \\
LSD & $\mathbf{0 . 6 7 8}$ & $\mathbf{0 . 1 6 6}$ & $\mathbf{0 . 0 9 8}$ & $\mathbf{2 . 6 8 3}$ \\
CV \% & $\mathbf{1 1 . 1 0}$ & $\mathbf{4 . 4 0}$ & $\mathbf{1 8 . 6 0}$ & $\mathbf{1 1 . 3 0}$ \\
\hline
\end{tabular}

\subsection{Tuber Quality Parameters}

In the present study, variety and $\mathrm{K}$ application had significant effect in all the tuber quality aspect studied. However, interaction treatments of K by variety had significant influence only on TSS and moisture percentage without any influence on specific gravity.

\subsubsection{Total Soluble Solids (TSS) $\left({ }^{\circ}\right.$ Brix)}

The $\mathrm{K}$ level treatment exhibited significant differences $(\mathrm{p}<0.001)$ in the TSS level of varieties. TSS level tends to decrease with increasing potassium doses (Table 3). The highest TSS $\left(5.58^{\circ}\right.$ Brix) was obtained from control. Minimum TSS $\left(5.00{ }^{\circ}\right.$ Brix) was recorded from plots treated with $300 \mathrm{~kg} \mathrm{~K}_{2} \mathrm{O} / \mathrm{ha}$. $\mathrm{K}$ application has a potential to decrease reducing sugar content of potato tubers by activating starch synthesis (Marschner, 1995). The result is in agreement with the finding of Pervez et al. (2013) where the TSS level was significantly affected by the application of K. However, Abd El-Latif et al. (2011) reported that application of K fertilizers had no any significant effect on tuber TSS level. There was also significant differences $(p<0.001)$ of TSS level among the varieties (Table 3). The highest $\left(5.44^{\circ} \mathrm{Brix}\right)$ was recorded from Ajiba followed by Zafira. This could be due to the inherited characteristic differences among the varieties used. This is fully supported by Baloch in (2010) who reported that potato varieties differ markedly in various plant characters including TSS content. Similarly, potato tuber quality characteristics are governed by both the variety of potato and the conditions under which it is 
grown (Van der Zaag, 1992). Interaction effects of $\mathrm{K}$ by variety were significant $(\mathrm{p}<0.001)$ for TSS. The TSS level decreased for Ajiba with increasing $\mathrm{K}_{2} \mathrm{O}$ application, while it had increased for Zafira as the dose increases from 0 to $150 \mathrm{~K}_{2} \mathrm{O}$ beyond which starts to decrease. On the other hand, Picasso had shown very low response of TSS to $\mathrm{K}_{2} \mathrm{O}$ application. Accordingly, highest TSS $\left(6.40^{\circ}\right.$ Brix) was produced by Ajiba in control (Figure 3). Previously, it was reported by Havlin, Beaton, Tisdale and Nelson (2005) that varieties or hybrids of crops response to production and quality varies depending on the inputs used.

\subsubsection{Specific Gravity}

Potassium application had significant $(\mathrm{p}<0.001)$ effect on specific gravity of potato tubers. As it is shown in Table 3 specific gravity had increased with increasing $\mathrm{K}$ levels from $0-150 \mathrm{~kg} \mathrm{~K} \mathrm{~K}_{2} \mathrm{O} / \mathrm{ha}$. Application of $150 \mathrm{~kg}$ $\mathrm{K}_{2} \mathrm{O}$ /ha produced highest (1.11) specific gravity. Increasing $\mathrm{K}$ application above this level had decreased specific gravity. In agreement to this finding Berger, Potterton and Hobson (1961) reported that K fertilization generally reduces specific gravity if applied in excess. Specific gravity is closely related to the tuber starch content or total solids and thus dry matter content of tubers (Dampney, Wale, \& Sinclair, 2011). Potassium application has the potential to decrease reducing sugar content of potato tubers by activating starch synthesis (Marschner, 1995) that has a tendency to increase tuber specific gravity. However, Noor (2010) reported that K application did not have significant effect on specific gravity. Based on varietal effect specific gravity was found to have significant $(p<0.001)$ differences among the varieties evaluated (Table 3). Highest specific gravity (1.12) was recorded from Picasso. Zafira produced the lowest (1.05) mean value. In a similar study Abong et al. (2010) found that specific gravity and dry matter contents had significant difference among potato varieties. The interaction of $\mathrm{K}$ and varieties had no significant influence on specific gravity. All the varieties evaluated responded to K application in a similar way and their tuber specific gravity had increased with increasing $\mathrm{K}$ application only in the range of $0-150 \mathrm{~K}_{2} \mathrm{O} \mathrm{kg} / \mathrm{ha}$ (Figure 3). Maximum and minimum specific gravity of these varieties was recorded at 150 $\mathrm{K}_{2} \mathrm{O} \mathrm{kg} / \mathrm{ha}$ and control, respectively. This implies that application of $150 \mathrm{~K}_{2} \mathrm{O} \mathrm{kg} / \mathrm{ha}$ was optimum for higher specific gravity. However, Havlin et al. (2005) reported that with a given environment, one variety may have greater response to applied nutrient than the other.

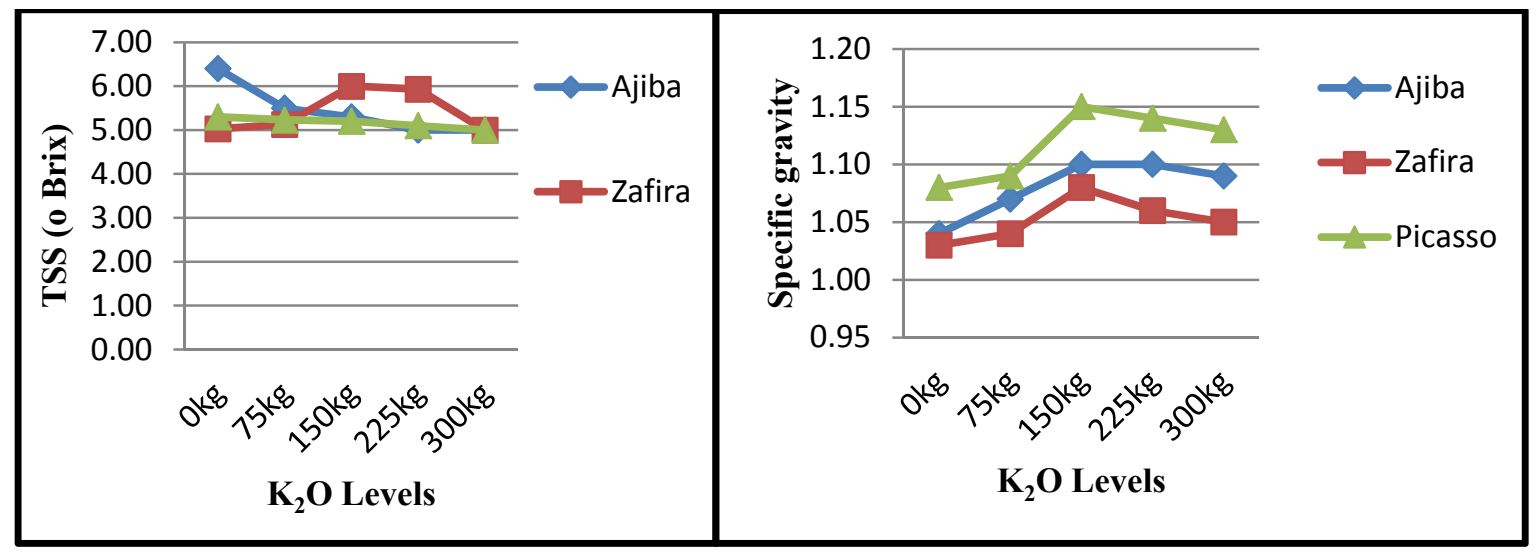

Figure 3. Interaction effects of K and potato varieties on tuber TSS (left) and specific gravity (right)

\subsubsection{Tuber Moisture Content (\%)}

Statistically $\mathrm{K}$ treatment was found to have significant effect on tuber moisture content. Tuber moisture content had increased in the range of $150-300 \mathrm{~kg} \mathrm{~K}_{2} \mathrm{O} / \mathrm{ha}$. Maximum tuber moisture content (83.83 \%) was obtained from the application of $300 \mathrm{~kg} \mathrm{~K} 2 \mathrm{O} / \mathrm{ha}$. Potassium plays vital role in water use efficiency of crops, maintaining the turgidity of plant cells and amount of water in plant cells so as to increase the amount of water in plant organ like tubers (Abd El-Latif et al., 2011). The result of current experiment is supported by the findings of (Bergmann, 1992) whom reported that with the application of $\mathrm{K}$, the water contents of the plasma volume were influenced increasing the water contents of the storage tissues and reducing the dry matter content. Based on varietal treatments, statistically tuber moisture content showed significant differences (Table 3). Ajiba exhibited low moisture content (82.40\%), while Zafira (83.30\%). Interaction of $\mathrm{K}$ and varieties had significant influences on moisture content of potato tuber. The varieties had great variation in their responses to $\mathrm{K}$ levels. Picasso shown decreased moisture content as the $\mathrm{K}$ level increased from $0-225 \mathrm{~kg} / \mathrm{ha}$ after which starts to increase. On the other hand, Ajiba and Zafira showed reduction in moisture content up to the level of $150 \mathrm{~kg} \mathrm{~K} / \mathrm{O} / \mathrm{ha}$ then 
increased as level increased. This could be attributed to genetic make-up of varieties in which one variety may have greater or lesser response to applied nutrient than the other (Havlin et al., 2005).

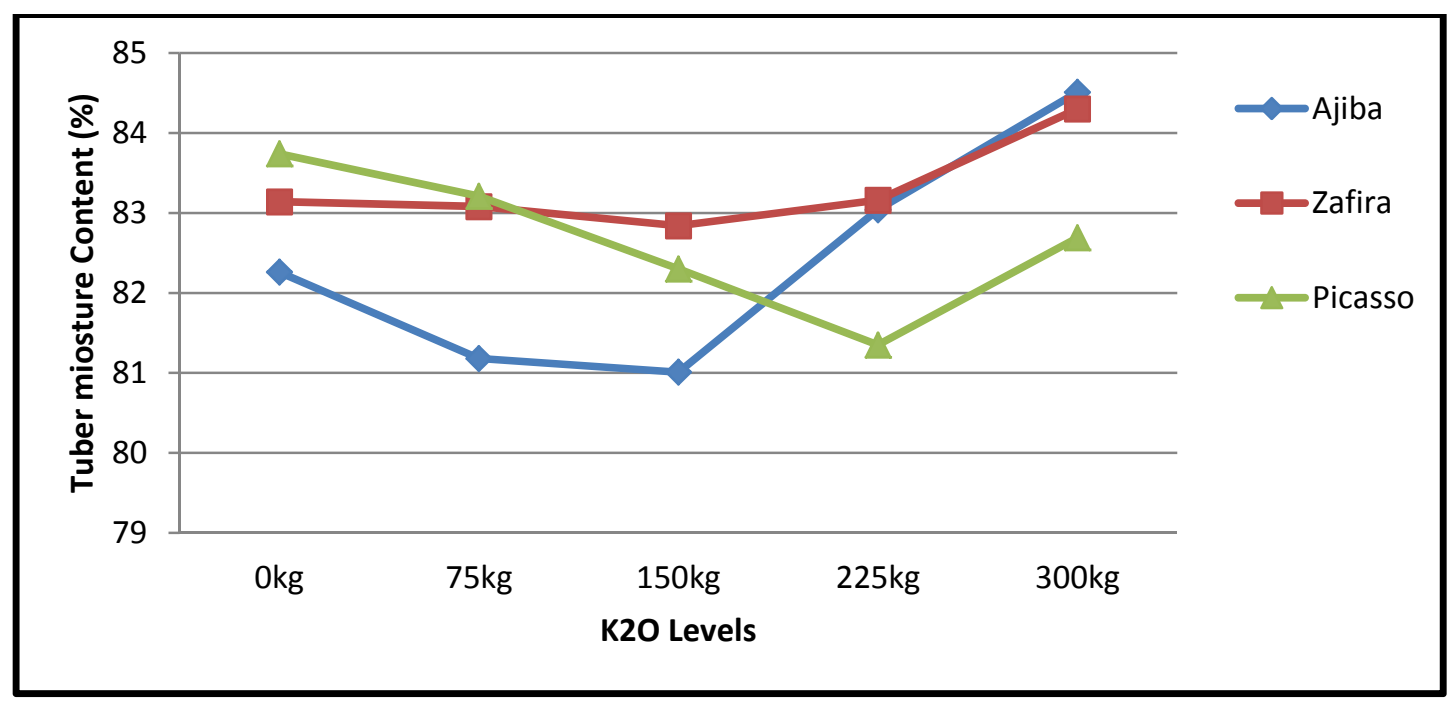

Figure 4. Interaction effects of $\mathrm{K}$ and potato varieties on Tuber moisture content (\%)

\subsection{Correlation among Yield and Quality Parameters}

The correlation analysis shown that, tuber number per plant had positive and significant correlation with tuber weight per plant $(\mathrm{r}=0.801)$ and total tuber yield $(\mathrm{r}=0.855)$. This indicates that as number of tubers produced by a single plant increases, total tuber weight per plant and overall tuber yield can be increased. However, it had negative and significant correlations with tuber diameter $(r=-0.416)$ and tuber specific gravity $(r=-0.306)$. As the number of tubers per plant increased the tubers produced will be of smaller size and lower specific gravity. This is in line with the findings of Van der Zaag (1992) who stated that tuber size of the harvested product depends on the total tuber yield and the number of tubers per $\mathrm{m}^{2}$. Total tuber yield had positive and significant correlation (0.462) with $\mathrm{K}$ application. This is because of the importance of $\mathrm{K}$ in carbohydrate formation and transformation and movement of starch from potato leaves to tubers (Van der Zaag, 1981). Tuber specific gravity and $\mathrm{K}$ were positively correlated $(\mathrm{r}=0.362)$ while, TSS and $\mathrm{K}$ application were negatively correlated $(\mathrm{r}=$ -0.325 ). This is ascribed to the activating role of $\mathrm{K}$ to starch synthesis through decreasing the reducing sugar content of potato tubers (Marschner, 1995).

Table 3. The effect of potassium and variety on the tuber components of potato

\begin{tabular}{lccc}
\hline $\mathbf{K}_{\mathbf{2}} \mathbf{O}(\mathbf{k g} / \mathbf{h a})$ & TSS $\left({ }^{\mathbf{}}\right.$ Brix) & Specific Gravity & Moisture content (\%) \\
\hline 0 & 5.58 & 1.05 & 83.05 \\
75 & 5.29 & 1.07 & 82.49 \\
150 & 5.5 & 1.11 & 82.05 \\
225 & 5.34 & 1.1 & 82.52 \\
300 & 5.00 & 1.09 & 83.83 \\
LSD (p=0.05) & $\mathbf{0 . 1 8 3}$ & $\mathbf{0 . 0 2 7}$ & $\mathbf{0 . 8 6 6}$ \\
CV \% & $\mathbf{3 . 5 0}$ & $\mathbf{2 . 6 0}$ & $\mathbf{1 . 1 0}$ \\
Varieties & & & \\
Ajiba & 5.44 & 1.08 & 82.40 \\
Zafira & 5.42 & 1.05 & 83.30 \\
Picasso & 5.17 & 1.12 & 82.66 \\
LSD (p=0.05) & $\mathbf{0 . 1 4 1}$ & $\mathbf{0 . 0 2 1}$ & $\mathbf{0 . 6 7 1}$ \\
CV \% & $\mathbf{3 . 5 0}$ & $\mathbf{2 . 6 0}$ & $\mathbf{1 . 1 0}$ \\
\hline
\end{tabular}




\section{Conclusion}

Potassium had significant effect on all yield and quality parameters of potato varieties studied. Application of K had consistent and positive effect on the yield of potato tubers. Maximum tuber yield (40.25 t/ha) was recorded from the application of $300 \mathrm{~kg} \mathrm{~K}_{2} \mathrm{O} / \mathrm{ha}$. Potato varieties had significant differences in their performance, and also shown significant differential response to $\mathrm{K}$ application. Ajiba was superior and high yielding in the study area. The highest yield (49.38 t/ha) was obtained from the variety of Ajiba in response to $300 \mathrm{~kg} \mathrm{~K}_{2} \mathrm{O} / \mathrm{ha}$. Despite $\mathrm{K}$ being one of the most vital macro nutrients of crops, it has never been introduced and used by potato growers in Eritrea. It is, therefore, recommended to carryout extensive experiments on screening for $\mathrm{K}$ need and dosage in major potato growing areas of the country and $\mathrm{K}$ levels above $300 \mathrm{~kg} / \mathrm{ha}$ need to be tested. It is, also recommended that to improve yield and quality of crops produced, $\mathrm{K}$ fertilizers should be introduced to Hamelmalo and other similar areas of the country.

\section{Acknowledgement}

The authors wish to thank the Eritrean National Board for Higher Education in collaboration with Hamelmalo Agricultural College (HAC) for funding the research project.

\section{References}

Abay, A., \& Sheleme, B. (2011). The influence of Potassium Fertilizer on the Production of Potato (Solanum tuberosu L.) at Kembata in Southern Ethiopia. Journal of Biology, Agriculture and Healthcare, 1(1), 1-12.

Abong, G. O., Okoth, M. W., Imungi, J. K., \& Kabira, J. N. (2010). Evaluation of Selected Kenyan Potato Cultivars for Processing into Potato Crisps. Agriculture and Biology Journal of North America, 1(5), 886-893. http://dx.doi.org/10.5251/ abjna.2010.1.5.886.893

Abd El-latif, K. M., Osman E. A. M., Abdullah, R., \& Abdelkader, N. (2011). Response of Potato Plants to Potassium Fertilizer Rates and Soil Moisture Deficit. Advances in Applied Science Research, 2(2), 388-397.

Abubaker, S., AbuRayyan, A., Amre A., Alzubil, Y., \& Hadidi, N. (2011). Impact of Cultivar and Growing Season on Potato under Center Pivot Irrigation System. World Journal of Agricultural Sciences, 7(6), 718-721.

Adhikary, B. H., \& Karki K. B. (2006). Effect of Potassium on Potato Tuber Production in Acid Soils of Malepatan, Pokhara. Nepal Agricultural Research Journal, 7, 42-48.

Ali, M. R, Costa, D. J., Abedin, M. J., Sayed, M. A., \& Basak, N. C. (2009). Effect of Fertilizer and Variety on the Yield of Sweet Potato. Bangladesh Journal of Agricultural Research, 34(30), 473-480. http://dx.doi.org/10.3329/bjar.v34i3.3974

Baloch, M. N. (2010). Vegetable crops. In M. N. Malik. Horticulture (pp. 490-491). Biotec Book. New Delhi, India.

Bansal, S. K., \& Trehan S. P. (2011). Effect of Potassium on Yield and Processing Quality Attributes of Potato. Karnataka Journal of Agricultural Sciences, 24(1), 48-54.

Berger, K. C., Potterton, P. E., \& Hobson, E. I. (1961). Yield Quality and Phosphorus Uptake of Potatoes as Influenced by Placement and Composition of Potassium Fertilizers. American Potato Journal, 38, 272-285. http://dx.doi.org/10.1007/BF02862172

Bergmann, W. (1992). Nutritional disorders of plants development, visual and analytic diagnosis. Gustav Fischer, Jena.

Biniam, M. G., Githiri S. M., Tadesse, M., \& Kasili, W. R. (2014). Diagnostic Survey on Potato Production Practices in Eritrea. Journal of Agricultural and Biological Science, 9(12), 444-453.

CIP. (2006). Procedures for standard evaluation trials of advanced potato clones. An International Cooperators' Guide.

Dampney, P., Wale, S., \& Sinclair, A. (2011). Review Potash Requirements of Potatoes. Report of Agriculture \& Horticulture Development Board 2011.

FAO. (2009). Potato and food price inflation. International Year of the Potato 2008.

Gildemacher, P. R., Kaguongo, W., Ortiz, O., Tesfaye, A., Woldegiorgis, G., Wagoire, W. W., ... Struik P. C. (2009). Improving Potato Production in Kenya, Uganda and Ethiopia: A System Diagnosis. Potato Research, 52, 173-205. http://dx.doi.org/10.1007/s11540-009-9127-4

Havlin, J. L., Beaton, J. D., Tisdale, S. L., \& Nelson W. L. (2005). Soil fertility and fertilizers: An introduction to 
nutrient management (7th ed.). Pearson Educational, Inc, NJ, USA.

Hochmuth, G. J., \& Hanlon, E. A. (2000). IFAS standardized fertilization recommendations for vegetable crops. Circular 1152. University of Florida, Institute of Food and Agricultural Sciences, Gainesville, FL.

Kabir, J. N., \& Lemaga, B. (2003). Potato processing; Quality evaluation procedures for research and food industry applications in East and Central Africa. Kenya Agricultural Research Institute, Nairobi, Kenya.

Marschner, H. (1995). Mineral nutrition of higher plants (2nd ed.). Academic press limited, San Diego, USA.

Ministry of Agriculture. (2010). Vegetable crops research program. Annual report of National Agricultural Research Institute. Halhale, Eritrea.

Murphy, H. F. (1968). A report on the Fertility status and other data on some soils of Ethiopia, Bulletin, College of Agriculture, Haile Sellasie I University, Experiment station, Dire Dawa, Ethiopia, No 44.

NIVAP. (2011). Netherland catalogue of potato variety. AC Den Haag, the Netherlands. Retrieved November 20, 2014, from www.nivap.nl

Noor, M. A. (2010). Physiomorphological Determination of Potato Crop Regulated by Potassium Management. (Doctoral thesis) submitted to Institute of Horticultural Sciences University of Agriculture, Faislabad, Pakistan.

Peirce, L. C. (1987). Vegetables: Characteristics, Production and Marketing. John Wiley and Sons, Inc.

Pervez, M. A., Ayyub, M. I. C. M., Shabeen, M. R., \& Noor, M. A. (2013). Determination of Physiomorphological Characteristics of Potato Crop Regulated by Potassium Management. Pakistan Journal of Agricultural Sciences, 50(4), 611-615.

Rana, M. K. (2008). Olericulture in India. Kalyani Publishers, Ludiana; India.

Tindall, T., \& Westermann, D. T. (1994). Potassium fertility management of potatoes. University of Idaho Potato School (Mimeo). Idaho State Univ., Pocatello, ID.

Vaezzadeh, M., \& Naderidarbaghshahi, M. (2012). The Effect of Various Nitrogen Fertilizer Amounts on Yield and Nitrate Accumulation in Tubers of Two Potato Cultivars in Cold Regions of Isfahan (Iran). International Journal of Agriculture and Crop Sciences, 4(22), 1688-1691.

Van der Zaag, P. (1981). Soil fertility requirements for potato production. Technical information bulletin, December 1981, 14, CIP, Lima, Peru.

Van der Zaag, W. D. E. (1992). Potatoes and their production in the Netherlands (3rd ed.). Netherlands Potato Consultative Institute, CH the Hague, the Netherlands. Retrieved December 23, 2014, from www.potato.nl

Wassie, H. (2009). On Farm Verification of Potassium Fertilize Effect on the Yield of Irish Potato Grown on Acidic Soils of HagereSelam, Southern Ethiopia. Ethiopian Journal of Natural Resources, 11(2), 207-22.

Wibowo, C., Wijaya, K., Sumartono, G. H., \& Pawelzik, E. (2014). Effect of Potassium Level on Quality traits of Indonesian Potato Tubers. Asia Pacific Journal of Sustainable Agriculture Food and Energy, 2(1), 11-16.

\section{Copyrights}

Copyright for this article is retained by the author(s), with first publication rights granted to the journal.

This is an open-access article distributed under the terms and conditions of the Creative Commons Attribution license (http://creativecommons.org/licenses/by/3.0/). 